\title{
HUBUNGAN FAKTOR DETERMINAN DENGAN KEJADIAN DEMAM TIFOID PADA PASIEN RAWAT INAPDI RUMAH SAKIT PERTAMINA BINTANG AMIN TAHUN 2018
}

\author{
Festy Ladyani Mustofa' ${ }^{1}$ Rakhmi Rafie ${ }^{2}$, Bonita Megamelina ${ }^{3}$ \\ ${ }^{1}$ Departemen Gizi Medik Fakultas Kedokteran Universitas Malahayati \\ ${ }^{2}$ Departemen Anatomi Fakultas Kedokteran Universitas Malahayati \\ ${ }^{3}$ Program Studi Kedokteran Fakultas Kedokteran Universitas Malahayati
}

[email korespondensi: bonita2429e@gmail.com]

\begin{abstract}
Relationship Between Determinant Factor With The Types of Typhoid Fever In Hospital Patients In Pertamina Bintang Amin Bandar Lampung Hospital 2018. Typhoid fever is an acute infection of the digestive tract because of Salmonella typhi. Typhoid fever is closely related to personal hygiene and sanitation. However, there are some determinant factors such as agent, host (age, gender, history of typhoid fever, education) and environment. To determine the determinant factors associated with the incidence of typhoid fever in hospitalized patients at Pertamina Bintang Amin Hospital Bandar Lampung in 2018. The types of research is an analytic survey research with cross sectional research design. Sampling technique is simple random sampling. Research instrument is medical record. The data were analyzed by Chi-square test. The result showed that there was a relationship between age $(p=0.025, O R=2.49)$, gender $(p=0.026$, $O R=2.29)$, education $(p=0.020, O R=2.28)$ and history of typhoid fever $(p=0.028$, $\mathrm{OR}=3.59$ ). There is a significant relationship between age, gender, education and history of typhoid fever with the incidence of typhoid fever with $p$-value $<0.05$. The most affect factor is history of typhoid fever with p-value 0.028 .
\end{abstract}

Keywords: Determinant factor, Typhoid fever, Inpatient

Abstrak:HubunganFaktorDeterminanDenganKejadianDemamTifoidPadaPasi enRawatInapDi RumahSakitPertaminaBintang Amin Tahun 2018. Demam tifoid adalah infeksi akut pada saluran pencernaan yang disebabkan oleh Salmonella typhi. Penyakit demam tifoid sangat erat kaitannya dengan higiene perorangan dan sanitasi lingkungan rumah. Namun, terdapat faktor determinan lain yang memengaruhi seperti agen, host (usia, jenis kelamin, riwayat demam tifoid, pendidikan), dan lingkungan. Mengetahui faktor determinan yang berhubungan dengan kejadian demam tifoid pada pasien rawat inap di rumah sakit pertamina bintang amin bandar lampung tahun 2018. Jenis penelitian ini merupakan penelitian survey analitik dengan desain studi kasus potong silang. Teknik pengambilan sample berupa simple random sampling. Instrument penelitian berupa rekam medik. Data dianalilis dengan uj Chi-square. Menunjukkan bahwa terdapat hubungan antara usia $(p=0.025, O R=2.49)$, jenis kelamin $(p=0.026, O R=2.29)$, pendidikan $(p=0.020, O R=2.28)$ dan riwayat demam tifoid sebelumnya $(p=0.028$, $\mathrm{OR}=3.59$ ). Terdapat hubungan yang signifikan antara usia, jenis kelamin, pendidikan dan riwayat demam tifoid sebelumnya dengan kejadian demam tifoid dengan $p$-value 0.05 . Faktor yang paling mempengaruhi yaitu riwayat demam tifoid.

Kata Kunci: Faktor determinan, Demam tifoid, Rawat inap 


\section{PENDAHULUAN}

Penyakit tropis merupakan penyakit yang menyerang di daerah beriklim tropis. Indonesia termasuk negara beriklim tropis, sehingga penyakit tropis mudah berkembang. Penyakit tropis dapat disebabkan oleh bakteri, virus dan parasit. Salah satu jenis penyakit diantaranya adalah demam typoid (Kurniasih\& Tursina, 2017). Demam tifoid adalah infeksi akut pada saluran pencernaan yang disebabkan oleh Salmonella typhi. Demam paratifoid adalah penyakit sejenis yang disebabkan oleh Salmonella paratyphiA, B, dan C. Gejala dan tanda kedua penyakit tersebut hampir sama, tetapi manifestasi klinis paratifoid lebih ringan. Kedua penyakit di atas disebut tifoid. Terminologi lain yang sering digunakan adalah typhoid fever, paratyphoid fever, typhus, dan paratyphus abdominalis atau demam enterik (Widoyono, 2011).

Demam tifoid menyerang penduduk di semua negara. Seperti penyakit menular lainnya, tifoid banyak ditemukan di negara berkembang di mana higiene pribadi dan sanitasi lingkungannya kurang baik. Prevalensi kasus bervariasi tergantung lokasi, kondisi lingkungan setempat, dan perilaku masyarakat. Angka insidensi di seluruh dunia sekitar 17 juta per tahun dengan 600.000 orang meninggal karena penyakit ini. WHO memperkirakan $70 \%$ kematian terjadi di Asia. Prevalensi di Amerika Latin sekitar 150 per $100.000(0,15 \%)$ penduduk setiap tahunnya, sedangkan prevalensi di Asia jauh lebih banyak yaitu sekitar 900 per $100.000(0,9 \%)$ penduduk per tahun. Indonesia merupakan negara endemik demam tifoid. Diperkirakan terdapat 800 penderita per 100.000 $(0,8 \%)$ penduduk setiap tahun yang ditemukan sepanjang tahun (Widoyono, 2011) dan setiap tahunnya sekitar 50.000 orang meninggal dari jumlah penderita typhoid (Putri, 2016). Berdasarkan Badan Pusat Statistik Provinsi Lampung tahun 2014 jumlah kejadian demam tifoid di puskesmas sebesar 37.708 kasus dan di Rumah
Sakit sebesar 210 kasus pada pasien rawat jalan dan 96 kasus pada pasien rawat inap (Badan Pusat Statistik, 2014).

Berdasarkan data yang diperoleh dari rekam medik di RS Pertamina Bintang Amin Bandar Lampung, insiden demam typhoid pada tahun 2015 sebesar 47 kasus, tahun 2016 sebesar 31 kasus, tahun 2017 sebesar 214 kasus, dan pada tahun 2018 sebesar 222 pasien rawat jalan dan 1.317 pasien rawat inap. Dari data yang diperoleh tersebut, didapatkan bahwa demam typhoid termasuk dalam sepuluh penyakit terbesar di Rumah Sakit Pertamina Bintang Amin dengan demam typhoid menduduki nomor satu dari sepuluh penyakit lainnya (RS Pertamina Bintang Amin, 2018). Indonesia, insidens demam tifoid banyak dijumpai pada populasi yang berusia 3-19 tahun (Putri, 2017). Kejadian demam tifoid di Indonesia yang berkaitan dengan rumah tangga, yaitu adanya anggota keluarga dengan riwayat terkena demam tifoid, tidak adanya sabun untuk mencuci tangan, menggunakan piring yang sama untuk makan, dan tidak tersedianya tempat buang air besar dalam rumah. Determinan karakteristik individu yang dipakai adalah jenis kelamin, beberapa literatur menyatakan jenis kelamin perlu diukur sebagai determinan karena ada beberapa teori gen yang menyebutkan adanya perbedaan strukur gen pada laki-laki dan perempuan akan dapat menyebabkan respon terhadap suatu penyakit, atau juga kemungkinan terjadi perbedaan aktivitas antara dua kelompok tersebut. Sedang umur, hal ini untuk mengetahui resiko yang terjadi dari setiap golongan umur, seperti umur tua diyakini makin banyak terpapar berbagai macam penyakit menular, dan imunitas semakin turun, dan juga diyakini adanya perbedaan pola hidup dan aktivitas. Untuk determinan karakteristik keluarga meliputi pendidikan, pekerjaan, pengeluaran perkapita, dan jumlah balita dalam keluarga (Raflizar, 2009). 
Faktor determinan lain yang berhubungan dengan kejadian demam tifoid yaitu faktor agen, faktor host (usia, jenis kelamin, status gizi, pendidikan, dan riwayat demam tifoid), dan faktor lingkungan (Putri, 2016).

\section{METODE}

Pada penelitian ini bertujuan untuk mengetahui faktor determinan yang berhubungan dengan kejadian demam tifoid pada pasien rawat inap di rumah sakit Pertamina Bintang Amin Bandar Lampung tahun 2018. Desain yang digunakan dalam penelitian ini ada Cross Sectional yaitu suatu penelitian untuk mempelajari dinamika korelasi antara faktor-faktor risiko dengan efek, dengan cara pendekatan, observasi atau pengumpulan data sekaligus pada suatu saat. Waktu penelitian adalah bulan Janurai tahun 2020 yang dlakukan di RS
Pertamina Bntang Amin Bandar Lampung. Populasi dalam penelitian ini adalah semua pasien rawat inap yang positif terdiagnosis demam tifoid dan tercatat dalam rekam medik di RSPBA periode 2018 berjumlah 1.317 pasien. Dengan menggunakan rumus slovin dan tekhnik sampling simple random sampling dengan memperhatikan krteria inklusi dan ekslusi didapatkan sampel sebanyak 307 pasien.

Data yang diambil merupakan data sekunder. Teknik analisis data pada penelitian ini menggunakan ujiChisquare dengan p-value 0.05. Data yang diperoleh dianalisa dengan SPSS menggunakan uji univariat dan bivariat dimana data akan dicari distribusi frekuensinya serta menganalisa hubungan variabel dependen dan independen.

HASIL

Analisis Univariat

Tabel 1. Distribusi Frekuensi Responden Berdasarkan Usia

\begin{tabular}{|c|c|c|}
\hline Usia & Frekuensi & Persentase \\
\hline TidakBerisiko & 189 & 61.6 \\
\hline Berisiko & 118 & 38.4 \\
\hline Total & 307 & 100 \\
\hline
\end{tabular}

Berdasarkan tabel 1 di atas dapat dilihat dari 307 responden didapatkan sebagian besar pada usia tidak berisiko sebanyak 189 orang (61.6\%) dan usia berisiko ( $<20$ tahun) sebanyak 118 orang $(38.4 \%)$.

Tabel 2. Distribusi Frekuensi Responden Berdasarkan Jenis Kelamin

\begin{tabular}{lcc}
\hline \multicolumn{1}{c}{ Jenis Kelamin } & Frekuensi & Persentase \\
\hline Wanita & 163 & 53.1 \\
Laki-Laki & 144 & 38.4 \\
\hline \multicolumn{1}{c}{ Total } & $\mathbf{3 0 7}$ & $\mathbf{1 0 0}$ \\
\hline
\end{tabular}

Dari tabel 2 di atas dapat dilihat dari 307 responden didapatkan sebagian besar pada jenis kelamin wanita sebanyak 163 orang (53.1\%) dan pada jenis kelamin laki-laki sebanyak $144(38.4 \%)$.

Tabel 3.Distribusi Frekuensi Responden Berdasarkan Pendidikan

\begin{tabular}{lcc}
\hline \multicolumn{1}{c}{ Pendidikan } & Frekuensi & Persentase \\
\hline Tinggi & 136 & 44.3 \\
Rendah & 171 & 55.7 \\
\hline
\end{tabular}


Dari tabel 3 di atas dapat dilihat dari 307 responden didapatkan sebagian besar pada pendidikan rendah sebanyak 171 orang (55.7\%) dan pada pendidikan tinggi sebanyak 136 orang $(44.3 \%)$.

Tabel 4. Distribusi Frekuensi Responden Berdasarkan Riwayat Demam Tifoid

\begin{tabular}{lccc}
\hline \multicolumn{2}{c}{ Riwayat Demam } & Frekuensi & Persentase \\
Tifoid & 68 & 22.1 \\
Ya & & 239 & 77.9 \\
Tidak & Total & $\mathbf{3 0 7}$ & $\mathbf{1 0 0}$ \\
\hline
\end{tabular}

Dari tabel 5 di atas dapat dilihat dari 307 responden didapatkan sebagian besar pada yang tidak memiliki riwayat demam tifoid sebelumnya sebanyak 239 orang (77.9\%) dan yang memiliki riwayat demam tifoid sebelumnya sebanyak 68 orang $(22.1 \%)$.

Tabel 5.Distribusi Frekuensi Responden Berdasarkan Terdiagnosa Demam Tifoid

\begin{tabular}{|c|c|c|}
\hline Demam Tifoid & Frekuensi & Persentase \\
\hline Negatif & 37 & 12.1 \\
\hline Positif & 270 & 87.9 \\
\hline Total & 307 & 100 \\
\hline
\end{tabular}

Dari tabel 6 di atas dapat dilihat dari 307 responden didapatkan sebagian besar pada yang positif demam tifoid sebanyak 270 orang (87.9\%) dan yang negatif demam tifoid sebanyak 37 orang (12.1\%).

\section{Analisis Bivariat}

Tabel 6.Analisa Hubungan Usia Dengan Kejadian Demam Tifoid

\begin{tabular}{|c|c|c|c|c|c|c|c|c|}
\hline \multirow{3}{*}{ Umur } & \multicolumn{4}{|c|}{ DemamTifoid } & \multirow{2}{*}{\multicolumn{2}{|c|}{ Total }} & \multirow{3}{*}{$\begin{array}{c}\text { P- } \\
\text { value }\end{array}$} & \multirow{3}{*}{$\begin{array}{c}\text { OR } \\
95 \% \mathrm{C} \\
\mathrm{I} \\
\end{array}$} \\
\hline & \multicolumn{2}{|c|}{ Negatif } & \multicolumn{2}{|c|}{ Positif } & & & & \\
\hline & $n$ & $\%$ & $n$ & $\%$ & $\mathbf{n}$ & $\%$ & & \\
\hline $\begin{array}{l}\text { TidakBer } \\
\text { isiko }\end{array}$ & 29 & 15.3 & 160 & 84.7 & 189 & $100 \%$ & \multirow{2}{*}{0.025} & \multirow{2}{*}{$\begin{array}{c}2.492 \\
(1.089- \\
5.656)\end{array}$} \\
\hline $\begin{array}{c}\text { Berisiko } \\
\text { Total }\end{array}$ & $\begin{array}{c}8 \\
37\end{array}$ & $\frac{6.8}{12.1}$ & $\frac{110}{270}$ & $\begin{array}{l}93.2 \\
87.9\end{array}$ & $\frac{118}{307}$ & $\begin{array}{l}100 \% \\
100 \% \\
\end{array}$ & & \\
\hline
\end{tabular}

Berdasarkan tabel 7 menunjukkan responden dengan kelompok umur tidak berisiko, positif demam tifoid sebanyak 160 orang (84.7\%). Sedangkan responden dengan kelompok umur berisiko, positif demam tifoid sebanyak 110 orang $(93.2 \%)$.
Dengan menggunakan uji Chisquare menunjukkan $p$-value $=0.025$ dimana kurang dari nilai kemaknaan yaitu $5 \%(0.05)$, hal tersebut menunjukkan terdapat hubugan yang signifikan antara umur dengan kejadian demam tifoid. 
Tabel 7. Analisa Hubungan Jenis Kelamin Dengan Kejadian Demam Tifoid

\begin{tabular}{|c|c|c|c|c|c|c|c|c|}
\hline \multirow{3}{*}{$\begin{array}{l}\text { JenisKe } \\
\text { lamin }\end{array}$} & \multicolumn{4}{|c|}{ DemamTifoid } & \multirow{2}{*}{\multicolumn{2}{|c|}{ Total }} & \multirow{3}{*}{$\begin{array}{c}\text { P- } \\
\text { value }\end{array}$} & \multirow{3}{*}{$\begin{array}{c}\text { OR } \\
95 \% \\
\text { CI }\end{array}$} \\
\hline & \multicolumn{2}{|c|}{ Negatif } & \multicolumn{2}{|c|}{ Positif } & & & & \\
\hline & $\mathbf{n}$ & $\%$ & $\mathbf{n}$ & $\%$ & $\mathbf{n}$ & $\%$ & & \\
\hline Wanita & 26 & 16.0 & 137 & 84.0 & 163 & $100 \%$ & \multirow{3}{*}{0.026} & \multirow{3}{*}{$\begin{array}{c}2.295 \\
(1.090- \\
4.830)\end{array}$} \\
\hline Laki-laki & 11 & 7.6 & 133 & 92.4 & 144 & $100 \%$ & & \\
\hline Total & 37 & 12.1 & 270 & 87.9 & 307 & $100 \%$ & & \\
\hline
\end{tabular}

Berdasarkan tabel 8 meunjukkan responden dengan kelompok wanita, positif demam tifoid sebanyak 137 orang $(84.0 \%)$. Sedangkan responden dengan kelompok laki-laki, positif demam tifoid sebanyak 133 orang (92.4\%).
Dengan menggunakan uji Chisquare menunjukkan $p$-value $=0.026$ dimana kurang dari nilai kemaknaan yaitu $5 \%(0.05)$, hal tersebut menunjukkan terdapat hubugan yang signifikan antara jenis kelamin dengan kejadian demam tifoid.

Tabel 8. Analisa Hubungan Pendidikan Dengan Kejadian Demam Tifoid

\begin{tabular}{|c|c|c|c|c|c|c|c|c|}
\hline \multirow{3}{*}{ Pendidikan } & \multicolumn{4}{|c|}{ DemamTifoid } & \multirow{2}{*}{\multicolumn{2}{|c|}{ Total }} & \multirow{3}{*}{$\begin{array}{c}\text { P- } \\
\text { value }\end{array}$} & \multirow{3}{*}{$\begin{array}{c}\text { OR } \\
95 \% \\
\text { CI }\end{array}$} \\
\hline & \multicolumn{2}{|c|}{ Negatif } & \multicolumn{2}{|c|}{ Positif } & & & & \\
\hline & n & $\%$ & $\mathbf{n}$ & $\%$ & n & $\%$ & & \\
\hline Tinggi & 23 & 16.9 & 113 & 83.1 & 136 & $100 \%$ & \multirow{3}{*}{0.020} & \multirow{3}{*}{$\begin{array}{c}2.283 \\
(1.126 \\
4.629)\end{array}$} \\
\hline Rendah & 14 & 8.2 & 157 & 91.8 & 171 & $100 \%$ & & \\
\hline Total & 37 & 12.1 & 270 & 87.9 & 307 & $100 \%$ & & \\
\hline
\end{tabular}

Berdasarkan tabel 9 meunjukkan responden dengan pendidikan tinggi, positif demam tifoid sebanyak 113 orang $(83.1 \%)$. Sedangkan responden dengan pendidikan rendah, positif demam tifoid sebanyak 157 orang $(91.8 \%)$.
Dengan menggunakan uji Chisquare menunjukkan $p$-value $=0.020$ dimana kurang dari nilai kemaknaan yaitu 5\% (0.05), hal tersebut menunjukkan terdapat hubugan yang signifikan antara pendidikan dengan kejadian demam tifoid.

\section{Tabel 9. Analisa Hubungan Riwayat Demam Tifoid Sebelumnya Dengan Kejadian Demam Tifoid}

\begin{tabular}{|c|c|c|c|c|c|c|c|c|}
\hline \multirow{3}{*}{$\begin{array}{c}\text { Riwayat } \\
\text { Demam } \\
\text { Tifoid }\end{array}$} & \multicolumn{4}{|c|}{ Demam Tifoid } & \multirow{2}{*}{\multicolumn{2}{|c|}{ Total }} & \multirow{3}{*}{$\begin{array}{c}\text { P- } \\
\text { value }\end{array}$} & \multirow{3}{*}{$\begin{array}{c}\text { OR } \\
95 \% \mathrm{C} \\
\text { I }\end{array}$} \\
\hline & \multicolumn{2}{|c|}{ Negatif } & \multicolumn{2}{|c|}{ Positif } & & & & \\
\hline & $\mathbf{F}$ & $\%$ & $\mathbf{F}$ & $\%$ & $\mathbf{F}$ & $\%$ & & \\
\hline Ya & 3 & 4.4 & 65 & 95.6 & 68 & $100 \%$ & & 3.593 \\
\hline Tidak & 34 & 14.2 & 205 & 85.8 & 239 & $100 \%$ & 0.028 & (1.068- \\
\hline Total & 37 & 12.1 & 270 & 87.9 & 307 & $100 \%$ & & $\begin{array}{c}12.081 \\
)\end{array}$ \\
\hline
\end{tabular}

Berdasarkan tabel 11 meunjukkan responden yang memiliki riwayat demam tifoid, positif demam tifoid sebanyak 65 orang (95.6\%). Sedangkan responden yang tidak memiliki riwayat demam tifoid, positif 
demam tifoid sebanyak 205 orang Chi-square menunjukkan $p$ value $=0.028$ dimana kurang dari nilai kemaknaan yaitu $5 \%(0.05)$, hal tersebut menunjukkan terdapat hubungan yang signifikan antara riwayat demam tifoid dengan kejadian demam tifoid.

\section{PEMBAHASAN}

\section{Hubungan \\ Kejadian Demam Tifoid}

Berdasarkan hasil penelitian di atas menunjukkan bahwa pasien dengan umur beresiko ( $<20$ tahun) yang positif demam tifoid sebanyak 110 orang (93.2\%) sedangkan pasien dengan umur tidak beresiko ( $\geq 20$ tahun) yang positif demam tifod sebanyak 160 orang $(84.7 \%)$. Hal tersebut berbeda dengan kebanyakan kasus demam tifoid yang di dapatkan usia 5-19 tahun.

Dari hasil analisa menggunakan uji Chi-square diperoleh dengan nilai $p$ value $0.025 \quad(<0.05)$ yang berarti terdapat hubungan yang signifikan antara usia responden dengan kejadian demam tifoid di RS Pertamina Bintang Amin. Dari analisis diatas didapatkan nilai $\mathrm{OR}=2.492$ yang menunjukkan bahwa usia yang tidak berisiko berpeluang 2.492 kali untuk terjadinya demam tifoid dibandingkan dengan usia berisiko.

Hasil penelitian ini sejalan dengan penelitian Putri (2016) di RSUD Tugurejo Semarang dimana terdapat hubungan yang bermakna antara usia dengan kejadian demam tifoid ( $p$ value $=0.001$ ).

Namun berbeda dengan hasil penelitian Pramitasari (2013) dengan diperoleh nilai $p$-value $=0,749$. Selain itu juga ada peneliti lain yang dilakukan oleh Ulfa (2018) di kota Semarang, menunjukkan hasil yang selaras bahwa tidak terdapat hubungan yang signifikan antara usia dengan kejadian demam tifoid dengan diperoleh nlai $p$-value $=1.00$. Hal ini menunjukkan tidak adanya hubungan yang signifikan antara usia dengan kejadian demam tifoid. Tidak terdapatnya hubungan antara usia
$(85.8 \%)$. Dengan menggunakan uji dengan kejadian demam tifoid kemungkinan dikarenakan pada usia sekolah, remaja, atau dewasa muda yang mempunyai kebiasaan ruang lingkup gerak yang tinggi sehingga dimungkinkan pada kelompok tersebut mengenal jajanan di luar rumah yang belum terjamin kebersihannya atau pada usia dewasa yang mengerti tentang kebersihan tetapi tidak menerapkan.

\section{Hubungan Jenis Kelamin dengan Kejadian Demam Tifoid}

Berdasarkan hasil penelitian di atas karakteristik jenis kelamin dari 307 pasien menunjukkan bahwa 163 orang $(53.1 \%)$ berjenis kelamin wanita dimana 137 pasien diantaranya positif terdiagnosa demam tifoid dan 144 orang $(46.95 \%)$ berjenis kelamin lakilaki dimana 133 pasien diantaranya positif terdiagnosa demam tifoid.

Dengan menggunakan uji Chisquare menunjukkan $p$-value $=0.026$ dimana kurang dari nilai kemaknaan yaitu 5\% (0.05), hal tersebut menunjukkan terdapat hubungan yang signifikan antara jenis kelamin dengan kejadian demam tifoid. Dari analisis diatas didapatkan nilai OR $=2.295$ yang menunjukkan bahwa jenis kelamin wanita berpeluang 2.295 kali untuk terjadinya demam tifoid dibandingkan dengan jenis kelamin laki-laki. Hasil penelitian ini sejalan dengan penelitian Pramitasari (2013) di Rumah Sakit Umum Daerah Ungaran dimana terdapat hubungan yang signifikan antara jenis kelamin dengan kejadian demam tifoid ( $p$-value $=$ 0.002).

Tetapi hasil ini tidak sejalan dengan penelitian Ulfa (2018) di Wilayah Kerja Puskesmas Pagiyanten kota Semarang dengan diperoleh nilai $p$-value $=1.00$. Selain itu juga ada peneliti lain yang dilakukan oleh Rustam (2012) di kota Surabaya, menunjukkan hasil yang selaras bahwa tidak terdapat hubungan yang signifikan antara jenis kelamin dengan kejadian demam tifoid dengan diperoleh nilai $p$-value $=0.707$. Hal ini 
menunjukkan tidak adanya hubungan yang signifikan antara jenis kelamin dengan kejadian demam tifoid. Berbeda dengan kebanyakan kasus dimana demam tifoid sering didapati pada yang berjenis kelamin laki-laki dikarenakan terdapat perbedaan aktivitas antara kelompok laki-laki dan wanita. Adanya perbedaan ini dimungkinkan karena dalam penelitian ini mayoritas responden yang diambil berdasar data rekam medik Rumah Sakit adalah perempuan. Namun tidak menutup kemungkinan bahwa penderita demam tifoid laki-laki juga memilik angka kejadian yang tinggi.

\section{Hubungan Pendidikan dengan Kejadian Demam Tifoid}

Berdasarkan hasil penelitian diketahui pasien dengan kategori pendidikan tinggi yang positif demam tifoid sebanyak 113 (83.1\%). Sedangkan pasien dengan kategori pendidikan rendah yang positif demam tifoid sebanyak 157 (91.8\%).

Dengan menggunakan uji Chisquare menunjukkan $p$-value $=0.020$ dimana kurang dari nilai kemaknaan yaitu 5\% (0.05), hal tersebut menunjukkan terdapat hubungan yang signifikan antara pendidikan dengan kejadian demam tifoid. Dari analisis diatas didapatkan nilai $\mathrm{OR}=2.283$ yang menunjukkan bahwa responden dengan pendidikan rendah berpeluang 2.283 kali untuk terjadinya demam tifoid dibandingkan dengan yang berpendidikan tinggi.

Hasil penelitian ini sejalan dengan penelitian Rustam (2012) di RSUD Salewangan Maros kota Surabaya dimana terdapat hubungan yang signifikan antara jenis kelamin dengan kejadian demam tifoid ( $p$-value $=0.000$ ). Terdapat juga penelitian lain yang dilakukan oleh Hudhah \& Hidajah (2018) dimana menunjukkan hasil yang selaras di Wilayah Kerja Puskesmas Gayam Kabupaten Sumenep dengan dipeoleh $p$-value = 0.020 . Tetapi hasil tersebut tidak sejalan dengan penelitian yang (0.05), hal tersebut menunjukkan terdapat hubungan yang signifikan dilakukan Pramitasari (2013) di Rumah Sakit Umum Daerah Ungaran dengan diperoleh nilai $p$-value $=0.295$ yang berarti tidak terdapat hubungan yang signifikan antara pendidikan dengan kejadian demam tifoid.

Pendidikan adalah usaha sadar dan terencana untuk mewujudkan suasana belajar dan proses pembelajaran agar secara aktif mengembangkan potensi dirinya (Undang-Undang Republik Indonesia, 2003). Variabel pendidikan merupakan suatu indikator yang kerap ditelaah dalam mengukur indeks pembangunan manusia suatu negara, melalui pengetahuan dan pendidikan ada beberapa perilaku yang berkontribusi terhadap derajat kesehatan (Depkes RI, 2006).

Pendidikan formal mengembangkan pola kelakuan tertentu sesuai dengan apa yang diharapkan oleh masyarakat. Dalam hal ini pendidikan merupakan salah satu kompetensi yang dituntut dari masyarakat dalam rangka menanamkan perilaku sehat. Sehingga terjadi perubahan perilaku seperti yang diharapkan dalam mencapai tingkat kesehatan yang optimal. Menurut Hendrik L Blum, salah satu faktor yang mempengaruhi derajat kesehatan adalah perilaku, karena sehat atau tidak sehatnya lingkungan sangat tergantung pada perilaku seseorang itu sendiri. Karena selain dipengaruh oleh kebiasaan juga dipengaruhi oleh pendidikan (Putri, 2017).

\section{Hubungan Riwayat Demam Tifoid dengan Kejadian Demam Tifoid}

Berdasarkan hasil penelitian diketahui pasien yang memiliki riwayat demam tifoid sebelumnya dan positif demam tifoid sebanyak 65 (95.6\%). Sedangkan pasien yang tidak memliki riwayat demam tifoid sebelumnya dan positif demam tifoid sebanyak 205 (85.8\%). Dengan menggunakan uji Chi-square menunjukkan $p$-value = 0.028 dimana kurang dari nilai kemaknaan yaitu $5 \%$ antara riwayat demam tifoid dengan kejadian demam tifoid. Dari analisis 
diatas didapatkan nilai $\mathrm{OR}=3.593$ yang menunjukkan bahwa responden yang tidak memiliki riwayat demam tifoid sebelumnya berpeluang 3.593 kali untuk terjadinya demam tifoid dibandingkan dengan yang memiliki riwayat demam tifoid.

Hasil penelitian ini sejalan dengan penelitian Mayasari \& Pratiwi (2009) di Wilayah Kerja Puskesmas Colomadu Karanganyar dimana terdapat hubungan yang signifikan antara riwayat demam tifoid dengan kejadian demam tifoid $(p$-value $=0.013)$. Berbeda dengan penelitian yang dilakukan oleh Putri (2016) di RSUD Tugurejo Semarang dengan diperoleh $p$-value $=0.346$.

Berdasarkan teori, riwayat demam tifoid dapat terjadi dan berlangsung dalam waktu yang pendek pada mereka yang mendapat infeksi ringan dengan demikian juga hanya menghasilkan kekebalan yang lemah. Riwayat demam tifoid akan terjadi bila pengobatan sebelumnya tidak adekuat, $10 \%$ dari demam tifoid yang tidak di obati akan mengakibatkan timbulnya riwayat demam tifoid. Yang memengaruhi terjadinya riwayat demam tifoid antara lain: keadaan imunitas atau daya tahan tubuh orang tersebut sehingga dalam keadaan seperti itu kuman dapat meningkatkan aktivitasnya kembali, kebersihan perorangan yang kurang meskipun lingkungan umumnya adalah baik, konsumsi makanan dan minuman yang beresiko (belum dimasak/direbus, dihinggapi lalat, tidak diperhatikan kebersihannya), gaya hidup, stress, dan sebagainya (Putri, 2016). Selain itu, akibat pengobatan yang tidak adekuat akan menyebabkan bakteri Salmonella bertahan di dalam kandung empedu, mengalir ke dalam usus sehingga menjadi karier intestinal (Widodo, 2014).

\section{KESIMPULAN}

Berdasarkan analisis data hasil penelitian mengenai hubungan faktor determinan dengan kejadian demam tifoid pada pasien rawat inap di Rumah Sakit Pertamina Bintang Amin Tahun
2018 diperoleh kesimpulan sebagai berikut :

1. Diketahui ada hubungan yang signifikan antara usia degan kejadian demam tifoid yang dirawat inap di RSPBA tahun 2018 dengan diperoleh nilai $p$-value $=0.025$

2. Diketahui ada hubungan yang signifikan antara jenis kelamin degan kejadian demam tifoid yang dirawat inap di RSPBA tahun 2018 dengan diperoleh nilai $\mathrm{p}$-value $=$ 0.026

3. Diketahui ada hubungan yang signifikan antara pendidikan degan kejadian demam tifoid yang dirawat inap di RSPBA tahun 2018 dengan diperoleh nilai $p$-value $=0.020$

4. Diketahui ada hubungan yang signifikan antara riwayat demam tifoid sebelumnya degan kejadian demam tifoid yang dirawat inap di RSPBA tahun 2018 dengan diperoleh nilai $\mathrm{p}$-value $=0.028$

\section{SARAN}

\section{A. Bagi Tempat Penelitian}

Diharapkan dapat meningkatkan program penanggulangan penyakit demam tifoid dalam hal ini terkait edukasi antara dokter dengan pasien. Kepada tenaga kesehatan khususnya dokter untuk dapat memahami hubungan usia, jenis kelamin, pendidikan, pekerjaan, dan riwayat demam tifoid sebelumnya dengan kejadian demam tifoid, sehngga dapat digunakan untuk mengedukasi orang tua pasien, keluarga pasien, atau pasien itu sendiri untuk menyusun strategi pencegahan dan penanggulangannya.

Selain itu, pemeriksaan yang digunakan untuk mendiagnosa demam tifoid perlu diganti karena uji widal yang digunakan di RS Pertamina Bintang Amin memiliki spesifisitas dan sensitivitas yang rendah.

\section{B. Bagi Masyarakat}

Bagi masyarakat sekitar agar perlunya kewaspadaan masyarakat terhadap penyakit demam tifoid dikarenakan insidensi dapat terjadi sepanjang tahhun dengan 
memperhatikan sanitas Ingkungan pemukiman.

\section{Bagi Peneliti Selanjutya}

Hasil penelitian ini diharapkan dapat di analisis lebih lanjut dengan menambah atau memperluas variabel lainnya serta mengembangkan metode penelitian untuk mengetahui hubungan penelitan terhadap masing-masing varabel faktor determinan lain demam tifoid yang menjadi permasalahan di masyarakat.

\section{DAFTAR PUSTAKA}

Badan Pusat Statistik (BPS). "Jumlah Pasien Rawat Inap Menurut Jenis Penyakit".

(http://www.bps.go.id/diakses 6 Oktober 2019).

Departemen Kesehatan RI. 2006. Pedoman Pengendalian Demam Tifoid. Jakarta: Direktorat Jenderal Bina Pelayanan Medik.

Hudhah, M. H., \& Hidajah, A. C. (2018). Perilaku Ibu dalam Imunisasi Dasar Lengkap di Puskesmas Gayam Kabupaten Sumenep. Jurnal Promkes: The Indonesian Journal of Health Promotion and Health Education, 5(2):167-180.

Kurniasih, M. and Tursina, T.R.(2017). Diagnosis Penyakit TropisBerbasis Web Dengan Metode Certainty Factor. Jurnal Coding, 5(3):64.

Mayasari, D., \& Pratiwi, A. (2009). Hubungan respon imun dan stres dengan tingkat kekambuhan demam tifoid pada masyarakat di wilayah kerja Puskesmas Colomandu Karanganyar.Berita Ilmu Keperawatan, 2(1): 16.

Pramitasari, O.P. (2013). Faktor risiko kejadian penyakit demam tifoid pada penderita yang dirawat di rumah sakit umum daerah ungaran. Jurnal kesehatan Masyarakat Universitas Dipenogoro, 2(1):18787.

Putri, R. 2017. Hubungan Antara Tingkat Pendidikan dan Tingkat Pengetahuan Dengan Perilku Hidup Sehat Kualitas Lingkungan Rumah [Skripsi]. Bandar Lampung: Universitas Lampung.
Putri, TP. 2016. Hubungan usia, status gizi, dan riwayat demam tifoid dengan kejadian demam tifoid pada anak di RSUD Tugurejo Semarang [Skripsi]. Semarang: Universitas Muhammadiyah Semarang.

Raflizar, R. And Herawati, M.H.(2009).Hubungan Faktor Determinan Dengan Kejadian Tifoid Di Pulau Jawa. Indonesian Journal of Health Ecology, 9(4):1357-1365.

RS Pertamina Bintang Amin. 2018. Buku Rekam Medik Pasien. Bandar Lampung.

Rustam, M.Z.A. (2012). Hubungan Karakterstik Penderita Dengan Kejadian Demam Tifoid Pada Pasien Rawat Inap Di RSUD Salewangan Maros. STRADA Jurnal Ilmiah Kesehatan, 1(2):5762.

Ulfa F.,\& Handayani O.W.K. (2018). Kejadian Demam Tifoid di Wilayah Kerja Puskesmas Pagiyanten. HIGEIA (Journal of Public Health Research and Development), 2(2): 227-238.

Undang-Undang Republik Indonesia Nomor 20 Tahun 2003 Sistem Pendidikan Nasional. 8 Juli 2003. Lembaran Negara Republik Indonesia Tahun 2003 Nomor 4301. Jakarta.

Widodo J. Demam Tifoid. Dalam: Setiati S., Alwi I., Sudoyo A.W., Simadibrata M., Setiyohadi B., Syam A.F., penyunting. Buku Ajar Ilmu Penyakit Dalam. Edisi ke-6. Jakarta: Interna Publishing:2014.

Widoyono. (2011). Penyakit Tropis. Jakarta: Erlangga. 